\title{
The political economy of Greek-Turkish relations
}

\section{Dimitris Tsarouhas}

To cite this article: Dimitris Tsarouhas (2009) The political economy of Greek-Turkish relations, Southeast European and Black Sea Studies, 9:1-2, 39-57, DOI: 10.1080/14683850902723397

To link to this article: http://dx.doi.org/10.1080/14683850902723397

\section{Published online: 12 May 2009.}

Submit your article to this journal ¿

山ll Article views: 460

Q View related articles $\sqsubset$

Citing articles: 10 View citing articles 5 


\title{
The political economy of Greek-Turkish relations
}

\begin{abstract}
Dimitris Tsarouhas*
Department of International Relations, Bilkent University, Ankara, Turkey

This paper revisits the Greek-Turkish rapprochement, taking as its point of departure the two states' economic relations, and explores possible linkages to political cooperation. The paper finds growing collaboration in a context characterized by the proliferation of non-state actors in economic decisionmaking, and underlines the role played by FDI flows and trade decisions in stimulating cooperation. At the same time, it rejects an uncritical acceptance of economic functionalism and stresses the salience of politics, above and beyond Turkey's EU candidacy, to consolidate the gains from the rapprochement.
\end{abstract}

Keywords: Greece; Turkey; economic relations; rapprochement; interdependence

\section{Introduction}

Interstate relations have until recently been dominated by traditional understandings of diplomacy. State officials would engage in formal political negotiations over an agreed set of mutual concerns and seek politically acceptable solutions to disputes. Nevertheless, the last few decades have witnessed a reshaping of the international system and the emergence of centrifugal pressures away from the state. With the end of the Cold War, non-state actors have become increasingly influential in policymaking. Economic factors in particular are increasingly at the heart of diplomatic conduct, and the allocation of economic resources on a regional and global scale greatly influences power relations among states. This development has important theoretical and empirical implications. Theoretically, it tends to weaken the neorealist understanding of the international system (Waltz 1979) regarding its state-centric orientation and its indiscriminate use of a vaguely defined 'national interest' as the motivating factor of state behaviour. Empirically, it brings private actors, and in particular the business community understood as an entity retaining 'relative autonomy' from the state, closer to the centre of modern bilateral relations. One such bilateral relationship is that between Greece and Turkey.

The historical bond that binds two countries together is long, dating from the Ottoman years and finding everyday expression until today in shared cultural traits. However, the process of nation-state building has been painful for both sides. From the outset, the modern Greek state has been set in juxtaposition to a real or imagined 'other' represented by Turkey; or, better put, 'the (abstracted) Turk' (Millas 2006). While Greece has never carried the same weight in the formation of Turkey's selfidentification, the war immediately prior to the Republic's proclamation and its consequences, as well as the belief that Greece represented an adventurous opportunist

*Email: dimitris@bilkent.edu.tr 
aided by Europeans, has left a long-lasting impression. Nationalism as a potent political force has frequently troubled bilateral relations throughout the twentieth century and until today. Periods of détente and expressions of mutual sympathy have been short-lived, followed by tension and diplomatic (and sometimes military) posturing. The two NATO allies are often at each other's throat due to a variety of both real and imagined problems; the two countries almost went to war with each other a few times in the post-war era. The fact that Greece and Turkey could act as lighthouses of stability in a volatile region was going largely unnoticed; that is, until 10 years ago.

Stemming from a variety of reasons discussed in more depth below, the GreekTurkish rapprochement was initiated by the two countries' political elites in the late 1990s and found its symbolic expression in the then foreign ministers, İsmail Cem and George Papandreou. A network of interaction that now comprises not only political elites, but also civil society actors, as well as the economic communities of the two states, has been formed. As the nature and salience of diplomacy changes and economic relations become ever more significant, the role of the Greek and Turkish business communities in the rapprochement is of vital importance.

This paper looks at Greek-Turkish relations and the rapprochement under the prism of growing economic cooperation. It seeks to examine the extent to which economic partnership can have spillover effects in the political arena and whether 'lock-in' gains can be made in a way that would exclude the possibility of renewed hostilities in the future, including the possibility of armed confrontation. The latter point is important, as the prospect of war between Turkey and Greece has diminished but has not yet been consigned to history. Focusing on economic partnership, but inevitably including political factors in the analysis, the paper will then relate bilateral economic relations to Turkey's EU vocation. Empirical data outlined below will indicate the close relationship between Turkey's EU prospects (and Greece's membership) and the improvement in bilateral relations.

The first part of the paper deals with the changing realities of the international system as manifested in the reduced salience of states in diplomatic interaction, and the concomitant rise of non-state actors in the pursuit of policy objectives. The nonstate-centred literature on Greek-Turkish relations is briefly outlined in the same section. Following on from that, the second part discusses the evolution of Turkish and Greek political economy since the 1980s, the decade of economic liberalization and absorption of both states into a market-oriented system strongly linked to the internationalization of the world economy. What follow are an examination of economic relations ever since their flourishing in the early 2000s, and a brief assessment of future prospects. The paper's next part brings together the economic and the political, assessing Greek-Turkish relations from a macro perspective, before evaluating the relevance of theoretical schemes and the empirical record to date.

\section{Interdependence and the role of non-state actors}

Over the last 20 years or so, 'globalization' has become one of the most commonly used terms in the social sciences. Although pitfalls associated with indiscriminate use of the term are numerous, real changes in political and economic life have indeed occurred. One of these relates to the emergence of new types of relation beyond the conventional territorial boundaries of the state (Scholte 2000) and the parallel growth in interdependencies between a whole set of actors, be they political, economic, or social (Saner and Yiu 2003). The traditionally defined realm of diplomacy, restricted 
to exchanges between state officials, is now increasingly giving way to new, more complicated forms of interaction whereby economic actors vie for influence to promote their objectives. The role of business is in transformation, and the business community increasingly invests in resources that allow it to put forward policy recommendations, and create its own representation in other states (Saner and Yiu 2003). This process is clearly linked with globalization, to the extent that patterns of economic policymaking have become intensely polycentric that include state regulatory bodies and agencies next to international organizations, supra-state entities, and private corporations. International politics has given place to 'world politics', and non-state actors have played a key role in this process (Josselin and Wallace 2001).

Interdependence theory is of direct relevance to non-state actors, and also applicable to Greek-Turkish relations. Outlined in its most comprehensive form by Keohane and Nye, the theory of interdependence seeks to expose neorealism for the paucity of its state-centred approach (Keohane and Nye 1977). A series of changes in the international system, the later and slightly refined argument went, has led to 'complex interdependence' whereby the traditional salience of military force in the conduct of external relations has declined in parallel with growing economic and social interdependence (Keohane and Nye 1998). The superior character of the state as the key organizing principle in International Relations (IR) is thus put into doubt, as the notion of global governance brings new non-state actors and resources to the foreground of political conduct (Held 1999). Keohane and Nye's work has been vital in placing economic (inter)relations at the heart of IR, rejecting the exclusive usage of economic issues by International Political Economy (IPE) scholars as a method to understand international relations. Their work has also allowed subsequent scholars to expand upon the importance of the increasingly blurred divide between domestic and foreign policy, in that way articulating interdependence through both political and economic relations.

European integration is a manifestation of the increasingly blurred divide between foreign and domestic policy, reconfiguring the notion of national security to include low politics issues, and socializing political elites towards cooperative patterns of decision-making (Keridis 1999). What is more, non-state actors have made a key contribution in policymaking and new forms of EU governance, albeit in ways that traditional IR approaches have not always been quick to capture. Concretely, recent empirical data suggests that multinational corporations often act as part of wider advocacy coalitions in pursuit of policy objectives that can have far-reaching consequences for state policies (Cowles 2003). The issue of elite socialization and discursive change is also important here.

A number of scholars have worked on Greek-Turkish relations by adopting a nonstate-centric approach. The role of civil society in particular has often been highlighted in this regard. In both countries, and for reasons related to both socioeconomic and political factors, civil society has traditionally been weak (Sotiropoulos 1993; Toprak 1993). Moreover, until the end of the 1990s and despite the goodwill of individuals from both sides (see Politakis 1988; Volkan and Itzkowitz 1994), public opinion had sometimes acted as an impediment to the improvement of Greek-Turkish relations (Birand 1991). This, it has been argued, has at least partly stemmed from the popular image created by the historiography of the two states regarding each other, and the potent force of nationalism in the development of national identity across the Aegean (Özkırımlı and Sofos 2008). Since 1999, however, civil society initiatives aiming at the consolidation of peace and the creation of bonds of friendship across the 
Aegean have intensified their work (Belge 2004). Their commitment to building on mutual contacts of the pre-rapprochement era has found expression through various channels, and has been aided by increasing interaction among media representatives and journalists (Ker-Lindsay 2007).

Needless to say, the financial and administrative support of the European Union (EU) in this process has been crucial (Rumelili 2005). Economic relations in particular form a central part of non-state partnership and have gradually acquired a higher profile in the literature on bilateral relations (Ververidou 2001; Özel 2004). In a recent paper frequently cited below, Papadopoulos (2008) has explicitly addressed the issue of Greek-Turkish relations through the economic prism. By underlining a series of relevant factors likely to affect these relations in the future and adopting a cautious approach as to the effectiveness of 'economic diplomacy', Papadopoulos has made a major contribution to the literature. This paper is an attempt to build on such findings and explore the relationship between economic and political relations in the contemporary era.

\section{Globalization, europeanization and Greek-Turkish political economy}

The quest for economic development has been the defining feature of peripheral economies for most of the twentieth century. In the case of Greece, the post-1949 stable economic environment provided the right conditions for rapid growth. The Golden Age period ${ }^{1}$ saw marked increases in growth rates, averaging $6.5 \%$ in the $1950 \mathrm{~s}$ and $7.4 \%$ from 1961 to 1979 . Still, the post-war paradigm had successfully relied on the principle of monetary and fiscal stability, and its undermining in the 1970s had severe repercussions. The oil crisis led to higher inflation, a worsening balance of payments, and a marked decrease in foreign currency inflows affecting growth and employment. After 1974, successive governments pursued expansionist policies, which often led to lower growth, higher unemployment, and a loss of competitiveness (Tsakalotos 1991). By the early 1990s, economic woes were combined with external pressure from the EU, marking a shift in Greece's economic paradigm. Starting from 1991, successive governments sought to limit the role of the state and kick-start privatization schemes. Greek policymakers came under EU pressure to accept the need for economic reforms in line with the Union's Single Market program and its goal for an Economic and Monetary Union (EMU).

Employment expansion in the banking and finance sector through the 1990s occurred at the expense of manufacturing and handicrafts (Pagoulatos 2003). Geopolitical changes relating to the disintegration of Yugoslavia were a source of anxiety, but as privatization gathered pace over the 1990s and 2000s neighbouring countries became lucrative markets for a number of Greek investors. Following international trends, Greek business capital was strengthened by obtaining a viable exit option in foreign markets. Greece's entry into the Eurozone in the early 2000s and its attainment of a developed market status are, at least theoretically, promising developments regarding its attractiveness as an investment site.

In the Turkish case, étatism has been a central principle of economic policymaking since the establishment of the Republic. The state was not merely a regulator, but also employer and producer leading to inefficiencies in state-owned enterprises due to widespread clientelism. Rent-seeking by the private sector and macroeconomic instability persisted throughout the 1970s and 1980s (Ugur 2000) initiated by the political elite a few decades earlier (Öniş 2003). Persistent payment crises in the late 1950s and 
then again in the late 1970s led to the adoption of a neoliberal economic model by the beginning of the next decade, replacing post-1945 import substitution industrialization with an export-oriented pattern of liberalization (Şenses 2003). In line with financial globalization, the opening-up of the Turkish economy proceeded apace, as the capital account was fully liberalized in 1989 accompanied by a massive inflow of short-term international capital.

In the new political economy of Turkey, inefficient cycles of populism decreased but did not erase balance of payments crises, which were repeated in 1994 and 2001. Financial liberalization meant a growing ability for domestic borrowing, and this meant increasing real rates of interest and growing budget deficits. What has been described as Turkey's 'premature exposure to financial globalization' (Öniş 2003) led to a large increase in foreign-denominated liabilities, as Turkish banks engaged in arbitrage, gaining from high profits and an extremely lucrative tax and regulatory system. The 2001 crisis exposed the limits of such a system and this, coupled with the lack of fiscal discipline by successive coalition governments in the 1990s, led to an average inflation rate of $75 \%$ during that decade (Togan and Ersel 2003).

That last crisis provided a spur for the implementation of a series of reforms, under the watchful eye of the IMF and the EU. The Banking Regulation and Supervision Authority (Bankacılık Düzenleme ve Denetleme Kurumu, BDDK) has been given a high degree of autonomy and its regulatory role has been strengthened. Unprofitable Turkish conglomerates have been forced out of business, enabling market-oriented and competitive businesses to thrive in an antagonistic environment. In addition, the post-2001 political regime has been committed to the neoliberal orthodoxy emphasizing stable macroeconomic conditions and the creation of an environment conducive to global investment. The 2003 Law on Foreign Investment has drastically improved investment opportunities in Turkey by cutting red tape and offering serious investment incentives. This policy has proved successful in terms of a massive increase in FDI inflows (see Table 1), and in the context of the then-benign financial environment that directed investment opportunities to developing markets (Grigoriadis and Kamaras 2008).

The EU vocation of Turkey since the early 2000s has been of decisive influence in fostering a government-business consensus on the need to maintain macroeconomic stability and attract foreign investment. Most informed observers have viewed the EU factor either as an 'anchor' for the fulfilment of Turkish political and economic reforms, or as a 'commitment and credibility device' facilitating the process of reform by providing a reward mechanism at the end of a successful transformation process. Either way, both the Greek and Turkish economies had by the early 2000s acquired characteristics facilitating their growing interaction parallel to Turkey's EU candidacy status.

\section{Economic partnership: normalization and growth}

Until the 1980s, Greek-Turkish economic cooperation was minuscule, in both volume and significance. Political tension had everything to do with that. It was only during

Table 1. FDI inflows to Turkey, selected years (US\$ million).

\begin{tabular}{ccccccc}
\hline Year & $1990-2000$ (annual average) & 2003 & 2004 & 2005 & 2006 & 2007 \\
\hline Total & 791 & 1752 & 2883 & 9803 & 20,120 & 21,873 \\
\hline
\end{tabular}

Source: UNCTAD 2007; 2007 statistics are from the Undersecretariat of Treasury, Republic of Turkey. 
the 1988 Davos Meeting between Prime Ministers Özal and Papandreou that the establishment of a Turkish-Greek Business Council was seen as a forum of cooperation that would keep high politics issues aside. Turkey's previous experience in establishing such Councils on a bilateral basis with countries such as the UK, the United States, and Germany was important. Nonetheless, business attempts at cooperation were kept in the shadow of the complex political agenda. ${ }^{2}$

A characteristic example is Turkey's Customs Union (CU) membership, completed in 1996, which could have led to a significant increase in bilateral economic relations. That was expected in the light of the overcoming of administrative difficulties that had existed prior to the CU agreement. ${ }^{3}$ However, political differences between the two countries reached a peak in 1996 when skirmishes over the islet of Imia/Kardak almost led to open conflict (Athanassopoulou 1997). Tensions remained high throughout the late 1990s, with the 1999 Öcalan affair being a particular case in point. Instead of utilizing the opportunities related to CU, the two business communities could at best keep the economic and political channels of communication open. The attempted revitalization of the Greek-Turkish and Turkish-Greek councils in 1998 (Heraclides 2002) contributed to that process, in the sense that when the Öcalan crisis hit home, the two countries could escape negativism fairly quickly. In Davos, a team of 10 committed businessmen came together under very difficult conditions. By February 2008, a delegation of close to 1000 businessmen came together in Athens to further foster economic collaboration (To Vima, 3 February 2008).

Before examining economic cooperation in more detail, two points are in order. First, it is important to underline that the year 1999 is crucial for the rapprochement in multiple ways. First, the Kosovo crisis allowed the two states' Foreign Ministries to share a common platform and utilize a shared discourse of reconciliation. Secondly, foreign ministers Papandreou and Cem agreed to begin low politics talks and find common solutions to common problems. Thirdly, that year's catastrophic earthquakes in Turkey and Greece led to an unexpected and unprecedented outpouring of goodwill from both sides. Finally, and in the context of structural rethinking on the Greek part regarding the Greek-Turkish arms race and the role of Europeanization in promoting policy reform, Turkey became a EU candidate country in the EU Summit in December. Ever since, Greece has been unswerving in its support for Turkey's EU vocation (Evin 2005a).

Secondly, the economic areas examined here are trade and foreign direct investment (FDI) flows. Clearly, many more sectors are enmeshed in Greek-Turkish relations, with tourism and energy being obvious examples. However, the purpose of the paper is not to detail all potential areas of Greek and Turkish partnership, but to concentrate on those most closely associated to the paper's objectives. In that context, trade is the most obvious indicator of economic cooperation, and FDI flows tell us very much both about bilateral relations but, more importantly, the willingness of economic actors to assume the risks involved in capital transfers. Moreover, sectors such as energy form part of a much larger geopolitical puzzle embedded in the pattern of relations that Greece and Turkey have already established or intend to establish in the future (Greece's EU membership, Turkey's growing economic links to the Middle East and the Caspian basin, the Russia factor, and so on). Finally, whereas FDI is clearly correlated to structural changes in the global economic system, which increasingly offers exit opportunities to domestic capital, areas such as tourism and/or energy relate to more traditional notions of economic diplomacy. Important as these are, they are beyond the scope of the present study. 


\section{Trade}

Economic interaction between states comes at its simplest form through trade. For Turkish tradesmen, the 1999 rapprochement meant that their country's most developed neighbour became part of Turkish business export orientation. This would entail significant gains regarding market expansion. For Greece, on the other hand, the Turkish market was seen as an added part to the chain of trade diversification away from EU partners and towards the under-utilized potential of neighbouring countries. Having engaged in economic cooperation with business and state authorities from Southeast Europe since the 1990s (Bastian 2004), it was now Turkey's turn. From 1995 to 2006, the share of total Greek exports towards these states increased from $12 \%$ to $20 \%$, while Greece's market share to the EU-15 declined (Honjo and Chua 2008).

Trade was indeed one of the very first economic sectors to tune in the improved bilateral relations. In 1989 the total trade volume amounted to a mere \$200-220 million (Papadopoulos 2008). ${ }^{4}$ By 1994 this had grown to little more than $\$ 270$ million, but by 2007 it had risen to a staggering $\$ 3.2$ billion (Table 2). This is despite the 2001 Turkish economic crisis, which led to a temporary drop in the bilateral trade volume. Both sides hope for a snowball effect following the recent high-level political exchanges between the two countries. ${ }^{5}$ The visit by the Turkish prime minister Erdoğan to Greece in 2004 and the corresponding visit by Greek premier Karamanlis to Ankara in 2008 are both politically and symbolically crucial in fostering closer economic ties.

Looking at the pattern of trade more closely makes for an interesting reading. While Greek exports to Turkey have tended to concentrate on particular sectors, mainly raw cotton, plastic and petroleum products, Turkish exports to Greece are distinguished by a wider spread entailing a variety of industrial products. These range from clothing and textile to furniture, automotive parts and iron and steel parts (Papadopoulos 2008); Greece's export concentration means that it is more likely to be

Table 2. Bilateral Turkish-Greek trade, 1994-2007 (US\$ million).

\begin{tabular}{lccc}
\hline Year & Export (TR to GR) & Import (TR to GR) & Total trade volume \\
\hline $\mathbf{1 9 9 4}$ & 168.7 & 105.1 & $\mathbf{2 7 3 . 8}$ \\
$\mathbf{1 9 9 5}$ & 209.9 & 200.7 & $\mathbf{4 1 0 . 6}$ \\
$\mathbf{1 9 9 6}$ & 236.5 & 285.0 & $\mathbf{5 2 1 . 5}$ \\
$\mathbf{1 9 9 7}$ & 298.2 & 430.8 & $\mathbf{7 2 9 . 0}$ \\
$\mathbf{1 9 9 8}$ & 370.0 & 319.8 & $\mathbf{6 8 9 . 9}$ \\
$\mathbf{1 9 9 9}$ & 406.8 & 287.6 & $\mathbf{6 9 4 . 4}$ \\
$\mathbf{2 0 0 0}$ & 437.7 & 430.8 & $\mathbf{8 6 8 . 5}$ \\
$\mathbf{2 0 0 1}$ & 476.1 & 266.3 & $\mathbf{7 4 2 . 4}$ \\
$\mathbf{2 0 0 2}$ & 590.4 & 312.5 & $\mathbf{9 0 2 . 9}$ \\
$\mathbf{2 0 0 3}$ & 920.4 & 427.7 & $\mathbf{1 3 4 8 . 1}$ \\
$\mathbf{2 0 0 4}$ & 1171.2 & 594.4 & $\mathbf{1 7 6 5 . 2}$ \\
$\mathbf{2 0 0 5}$ & 1126.7 & 727.8 & $\mathbf{1 8 5 4 . 5}$ \\
$\mathbf{2 0 0 6}$ & 1602.6 & 1045.3 & $\mathbf{2 6 4 7 . 9}$ \\
$\mathbf{2 0 0 7}$ & $\mathbf{2 2 6 2 . 6}$ & $\mathbf{9 5 0 . 2}$ & $\mathbf{3 2 1 2 . 8}$ \\
\hline
\end{tabular}

Source: Istanbul Chamber of Industry 2008, 13. 
affected by the global economic slowdown (Papadopoulos, cited in Hope 2008). This gap has a quantitative dimension as well, reflected in the growing trade deficit of Greece with regard to Turkey. From a neorealist/relative gains perspective, this entails a significant exposure, as the Greek economy may lean towards increasing dependence on Turkish economic behaviour. Moreover, and as Papadopoulos (2008) aptly shows, whereas Turkey's importance for Greek exports is on the rise (ranking sixth in 2006), Greece constitutes a less significant market for Turkey and ranks very low, much lower than comparable states such as Bulgaria. Nonetheless, a 'relative gains' mentality that translates economic deficits into state power tends to concentrate on phenomena that could prove temporary in nature. After all, the cumulative trade volume has met with an astonishing increase recently, which means that both surpluses and deficits need to be examined in the context of expanding cooperation, and absolute benefits derived thereof for both economies.

Without doubt, the momentous growth in bilateral trade built on administrative adjustments and political agreements. These entered the agenda following the 1999 Papandreou-Cem talks, and ranged from tourism and organized crime to economic cooperation. The most significant agreement was the signing of the Double Taxation Agreement, in force since 2005. The negotiations leading to final agreement were long-lasting and strenuous, stretching over many years. The involvement of the Foreign Ministries of the two countries was unusually active, and the Turkish MFA sought to ensure that a final agreement could be made and obstacles overcome. Clearly, political willingness to reach an agreement played an important role in what are otherwise technical negotiations. ${ }^{6}$

The signing of this agreement was a particularly welcome step for those businessmen who saw it as a step in overcoming existent and excessive administrative burdens. However, such problems seem more related to public administration deficiencies in the two countries and have less to do with conscious attempts to impede collaboration. ${ }^{7}$ By way of example, reports in the Greek media point to the high bureaucratic barriers that entrepreneurship faces in the country, regardless of country of origin (Kathimerini, 30 May 2008). Still, Greek business to Turkey seems still plagued by certain psychological impediments, a phenomenon less evident in Turkish trade practices. ${ }^{8}$

\section{FDI and joint ventures}

When it comes to $\mathrm{FDI}^{9}$ and joint ventures, the likelihood of mutual gains through cooperation looked very positive immediately after the rapprochement began. For Turkey, Greece provides a profitable opportunity for the initiation of EU-funded projects. For Greek investors, Turkey is a lucrative market opening doors to the Middle East and Central Asia.

As with trade, agreements on a political level involving the Mutual Protection and Promotion of Investment signed in 2001 have accelerated investment plans. Progress on cross-border business partnerships has been evident in recent years. The improvement in political relations allowed business to pluralize their respective field of operations and engage in cooperation projects moving beyond the bilateral framework. The most characteristic example of such a move was the successful bid of a Turkish-Greek construction consortium in delivering the first phase of Blue City, an estimated $€ 20$ billion project $100 \mathrm{~km}$ from Oman's capital. The outward-oriented nature of the two companies involved and the complementary character of their expertise has been important in sealing the deal. A large number of Greek companies, estimated at around 80 


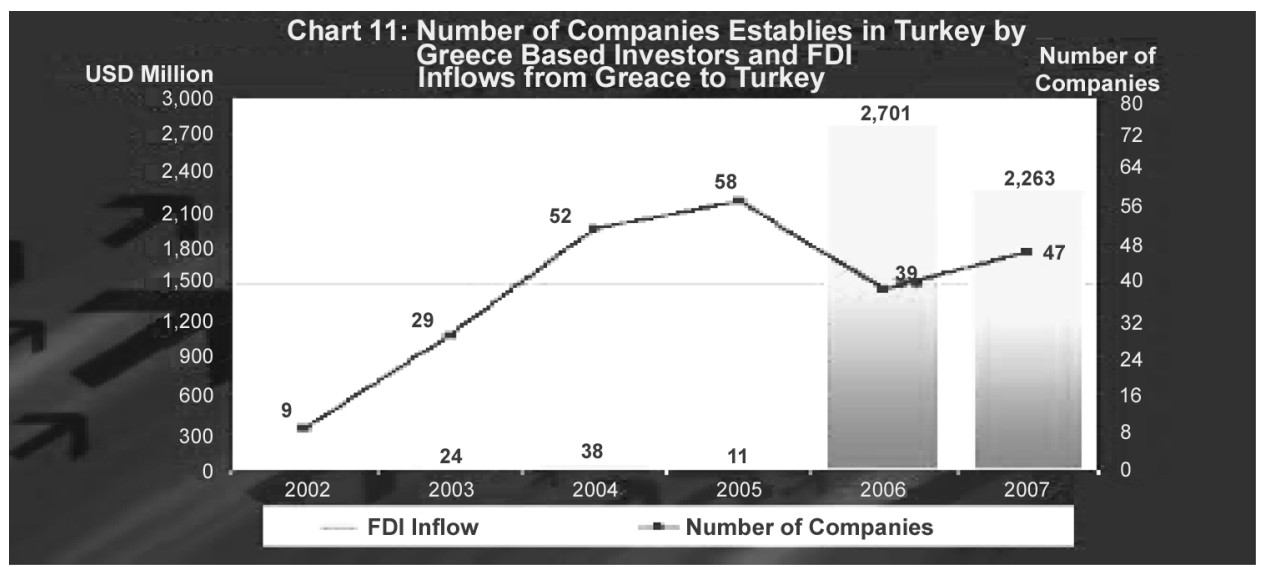

Figure 1. Number of Greek firms established in Turkey and FDI inflows from Greece to Turkey, 2002-2007 (US\$ million). Reproduced with permission of General Directorate for Foreign Investment.

Source: Undersecretariat of Treasury (Turkey) 2008, 47.

at the beginning of $2008,{ }^{10}$ are today present in the Turkish market through direct investment or synergies with Turkish counterparts. Contrary to the trade pattern, their nature varies from telecommunications and plastics to chemicals and the banking sector. Greek ventures to the Turkish market had increased by the early 2000s, but it was the acquisition of Finansbank, Turkey's fifth largest bank, by the National Bank of Greece (NBG) that changed the volume and nature of Greek FDI pouring into Turkey. The NBG deal enlarged economic relations, in both a quantitative and a qualitative sense.

To start with, the acquisition of Finansbank by NBG (involving a stake of $44 \%$, becoming 94\% in 2008) demonstrated the bank's confidence in the Turkish market, incorporating the risk involved in such a move, and concluding that the benefits outweighed existing risks. ${ }^{12}$ Part of NBG's strategy of internationalizing its operations, the acquisition of Finansbank has proven a profitable move. Data announced by the NBG Group for 2008 reported better-than-expected net profits of $€ 423$ million ( $+25 \%$ compared to the first quarter of 2007), with Finansbank operations contributing about one-third of overall profits (http://www.nbg.gr/wps/wcm/connect/ 64ac730049e3945f9f279fd1e5e6bdf2/Press+release+GR+2.pdf?MOD=AJPERES\& CACHEID=64ac730049e3945f9f279fd1e5e6bdf2).

Secondly, the quantitative dimension is important. From the beginning of the 1990s and until 2004, Greek FDI to Turkey amounted to about $\$ 500$ million. Only the NBG deal cost the Group approximately $\$ 5$ billion. The largest investment by a Greek firm in Turkey until then had cost approximately $\$ 40$ million (Figure 1). Thirdly, the deal acted as an 'icebreaker' for other firms wishing to reap the benefits of a similar move. In May 2006, Eurobank EFG acquired a 70\% stake of Tekfenbank. Though not of similar magnitude to the NBG deal, the latter acquisition is characteristic of a growing interest in the Turkish market. It has been asserted that the NBG deal attracted another 53 Greek companies as direct investors in Turkey (Papadopoulos 2008). This may suggest (though it is clearly too early to predict more Greek FDI outflows in a hazardous economic context) that the 'follow-the-leader' theoretical model of FDI (Kitonakis and Kontis 2008) corresponding to Greek FDI 


\begin{tabular}{llrr}
\hline Rank & Sector & Capital & $\%$ \\
\hline 1 & Netherlands & 11,824 & 24.6 \\
2 & USA & 5,232 & 10.9 \\
3 & Greece & $\mathbf{5 , 1 2 7}$ & $\mathbf{1 0 . 7}$ \\
4 & Belgium & 4,924 & 10.3 \\
5 & UAE & 3,194 & 6.6 \\
6 & France & 3,039 & 6.3 \\
7 & Germany & 2,053 & 4.3 \\
8 & UK & 1,756 & 3.7 \\
9 & Russia & 1,720 & 3.6 \\
10 & Austria & 1,487 & 3.1 \\
& Other & 7,675 & 16.0 \\
Total & & 48,031 & 100.0 \\
\hline
\end{tabular}

Figure 2. FDI inflows to Turkey, 2002-2007 (in US\$ million). Reproduced with permission of General Directorate for Foreign Investment.

Source: Foreign direct investment in Turkey 2007. Undersecretariat of Treasury (Turkey), 2008, 47.

investment in the Balkans could also apply to Greek firms' investment behaviour towards Turkey.

Finally, recent FDI flows from Greece to Turkey have elevated Greece's status in the rank of states investing in the now lucrative Turkish market, ranking third in the period 2002-2007 behind Holland and the United States (Undersecretariat of Treasury 2008, 46). Following a long period of stagnation, FDI directed to Turkey has risen inexorably in the last few years (Table 1). It needs to be emphasized that it is the NBG-Finansbank deal that mostly accounts for this rapid increase in FDI flow from Greece to Turkey; this, however, need not be a sign of limited potential in the future. After all, it was large deals in the finance sector that provided for the United States' second position and Belgium's fourth rank over the same period (Figure 2).

When it comes to Turkish business moves, a more nuanced picture emerges. The number of Turkish firms operating in Greece remains low, save for a few companies operating in the clothing industry joining those in tube manufacturing and IT services. Explanations vary, but the most important reasons relate to the nature of Turkish FDI outflow and Greek public administration. Firstly, Turkish FDI outflows have tended to shun away from Greece, preferring lower cost sites (Papadopoulos 2008). Secondly, Turkish capital owners have long complained of administrative difficulties in setting up shop in Greece; an attempt was made to address such problems through a new law, 3386/2005. This law aims to make things easier for non-EU nationals intending to operate in Greece, not least with regard to residence permits. In fact, problems of an excessively bureaucratic nature relate not only to Turkish FDI per se, but are revealed in the erratic character of Greek FDI inflows more generally (as shown in Table 3), a symbol of the country's long-run inability to attract foreign investment of substantial size and value.

\section{Future prospects and the $\mathbf{E U}$ variable}

Both the volume and character of Greek-Turkish economic relations has been transformed. Propelled by global economic change and encouraged by capital's new exit options, the two business communities have shown good reflexes in grasping 
Table 3. FDI inflows to Greece, selected years (US\$ million).

\begin{tabular}{ccccccc}
\hline Year & $1990-2000($ annual average) & 2003 & 2004 & 2005 & 2006 & 2007 \\
\hline Total & 916 & 1275 & 2101 & 607 & 5363 & 1400 \\
\hline
\end{tabular}

Source: UNCTAD 2007; the 2007 figure is based on EUROSTAT figures, STAT/08/71, May 2008.

Table 4. FDI in Turkey, 2002-2007 (US\$ million).

\begin{tabular}{llrr}
\hline Rank & Sector & Capital & \% \\
\hline 1 & Netherlands & 11,824 & 24.6 \\
2 & USA & 5232 & 10.9 \\
3 & Greece & 5127 & 10.7 \\
4 & Belgium & 4924 & 10.3 \\
5 & UAE & 3194 & 6.6 \\
6 & France & 3039 & 6.3 \\
7 & Germany & 2053 & 4.3 \\
8 & UK & 1756 & 3.7 \\
9 & Russia & 1720 & 3.6 \\
10 & Austria & 1487 & 3.1 \\
& Other & 7675 & 16.0 \\
& Total & $\mathbf{4 8 , 0 3 1}$ & $\mathbf{1 0 0 . 0}$ \\
\hline
\end{tabular}

Source: Undersecretariat of Treasury (Turkey) 2008, 46.

opportunities for collaboration. Nonetheless, the full potential of economic cooperation has yet to be realized.

Trade-wise, the recent growth is fully consistent with the attempts by the two governments to de-link political disagreements from economic issues. The two countries' geographical proximity is an important growth factor and the potential for better usage of existing links is very high. To name an example, land borders between the two countries constitute the sole currently available transit route. This practice hampers further trade development, as the Aegean provides a less costly and more efficient transit option. Recent attempts to link the Turkish coast with Greek islands could have had very practical results, considering that a large part of Greek goods transport originates in Turkey's third-largest city, Izmir. Nonetheless, the effective usage of sea routes will not materialize so long as the border disputes in the Aegean continue to blight not only bilateral trade but also, more importantly, bilateral political relations. Such disputes underline the salience of political variables in bilateral relations and complicate business operations. Having said that, further growth prospects in trade exist if one considers the regional concentration of Greek traffic to and from Turkey, focusing almost exclusively on Istanbul and the Aegean coast area. The rise of entrepreneurial activities elsewhere in Anatolia offers multiple possibilities to Greek enterprises and could assist them in the process of switching to value-added trade. For that to occur, both administrative issues and subjective/psychological matters would need to be addressed.

When it comes to FDI, the NBG deal has been decisive in encouraging the Greek banking sector towards the Turkish market. This is all the more important considering that the NBG move attracted criticism by opposition parties in the Greek parliament. 
It should be stressed, however, that the criticism had little to do, at least explicitly, with the operation site chosen by NBG and more with an alleged economic concerns as to the deal's effects on NBG profitability (Ferentinou 2007). Not all such ventures have been successful. While the state-owned agricultural bank of Turkey, Ziraat Bankası, acquired a permission to open up branches in Greece in the summer of 2007, Alpha Bank failed to acquire 50\% of the middle-sized Alternatifbank in 2007 when the BDDK blocked the sale (Ak 2007). Despite such setbacks, the road ahead looks promising: the Ziraat bank deal is worth around $€ 18$ million. More importantly, its realization will constitute the biggest Turkish investment in Greece (Financial Times, 1 June 2008).

Banking operations and acquisitions are inevitably linked to political variables. Low politics accords have been a first step in the rapprochement process. More recent agreements on establishing hotlines between the political and military leadership of the two states added to summer moratoria on naval and air force exercises. These indicate that the possibility of complete normalization may be greater than often assumed. Ongoing exploratory talks on deepening Confidence Building Measures (CBMs) and frequent exchanges on a bilateral and multilateral basis have removed the overt air of suspicion that had long clouded political relations. Nonetheless, the notion that gains made at the political level are irreversible should be treated with caution (Evin 2005b). The list of mutual grievances on issues of high politics remains intact, despite the fact that communication channels are open and instances of tension are now defused more quickly and effectively. Aside from the Cyprus question, which stands at the core of multiple transformative effects in the domestic and foreign policy paradigm of both countries (particularly Greece), the Aegean dispute over the precise sea and air border demarcation and the minorities issue remain unresolved. Those issues can potentially reverse improved relations if left unchecked, while at the same time, as mentioned above, hampering existing potential for trade cooperation.

Ever since the Helsinki summit of 1999, Greece has been one of the most consistent supporters of Turkish EU accession. In contrast to the confused messages emanating from elsewhere, Athens has made an important shift towards Turkey based on 'conditional rewards' rather than 'conditional sanctions' (Couloumbis 2003). Athens sought to demonstrate its practical commitment to Turkey's EU vocation through the establishment of a technical Task Force in 2000 to assist the process of Turkey's EU acquis approximation. Seminars under the aegis of the Task Force have had a positive impact in enhancing trust between the two administrations (Tsakonas 2001) and represent a tangible example of how Greece's EU experience can assist Turkey's acquis approximation.

The Greek support for Turkey's membership is to some extent a by-product of wider changes in Greek foreign policy. Deciding to utilize its soft power in the Balkans, not least by evoking its EU identity (Economides 2005), Greece redefined its foreign policy in the course of the 1990s. The zero-sum games of the past now gave way to a more nuanced approach. In many respects, this resulted from the realization that aligning Greek national interests with EU policy objectives offers the former the opportunity to benefit from the Union's enhanced status in the post-Cold War era. Greece, fully integrated to the Union's core mechanisms, stands a much better chance of succeeding in its strategic objectives than if it were to remain outside. The benefits of such an approach lie in the transformation of Greece's perception in Southeast Europe, offering it the chance to act as a guarantor of stability in a volatile neighbourhood. In that context, the Greek decision to move bilateral 
differences with Turkey on to the EU framework is premised on the expectation of the gradual socialization of Turkish foreign policy to EU norms and behavioural codes through its deeper exposure to them (Tsakonas and Dokos 2004, 113). In many respects, Turkey's recent foreign policy diversification has led to the articulation of a similar stabilization role for the country in the Black Sea and the Middle East, highlighting the cross-fertilization potential that exists between the two states. However, the early-2000s momentum has now subsided, and political vision is necessary to revitalize it.

The EU-Turkey relationship is a process of large geopolitical consequences, and its evolution is bound to affect bilateral relations. At the same time, in the absence of embedded cooperation between the two states, Turkey's EU vocation can prove a hindrance despite the current goodwill. This emerges as a possible scenario if one considers wider developments in EU integration and the difficulties of Turkey's accession ever since the beginning of accession negotiations.

From 2001 and until 2005, Turkey's reform efforts have won it deserved praise. Politically, economically, and socially, successive governments have exposed the country to EU scrutiny, pluralized the regime, and liberalized the country's legal framework (Tocci 2005). Ever since, however, the EU-Turkey relationship has experienced constant turbulence. On the one hand, Turkish authorities have visibly slowed down the reform process, citing administrative obstacles and domestic instability. At the same time, some EU governments now desire an ill-defined 'privileged partnership' with Turkey. Such a position is difficult to justify by any conventional standard. The increasing influence of Europe's public opinion on the Union's decision-making, part of an attempt to reduce the EU 'democratic deficit' and make it 'more relevant' to its citizens, is part of this story. With regard to enlargement, successive polls show that Western Europeans in particular remain very sceptical about further enlargement in general, and Turkey in particular (Eurobarometer 2006). Unsurprisingly, this has led to a marked turn towards Euroscepticism among the Turkish public, which is combined with a pervasive lack of knowledge about the EU, its role, functions, and decision-making procedures (Eurobarometer 2007). This is a potentially explosive combination.

Greek public opinion, the same polls reveal, maintains a firm position against Turkish membership, although it backs enlargement in general. The chasm between the cross-party consensus in Athens and public opinion is large, at least for now. Uncertainty on the EU-Turkey front could lead not only to the (currently topical) slowdown of reforms, but to their complete halt or even reversal. Should such a scenario materialize, Greek-Turkish relations are bound to suffer if the EU remains the sole anchor on which their relations depend. It is therefore imperative for political authorities to pluralize their cooperation by utilizing other international forums. The 'anchoring' argument can hardly be sustained with regard to those institutions, not least because of the EU's unique institutional features and 'soft power' credentials. Nonetheless, progress in Greek-Turkish relations need not be solely dependent on Turkey's EU membership aspirations. The point of diversification would not be to reduce the salience of the EU anchor; that would be costly and self-defeating. It is, however, vital in terms of minimizing the harm done through a potential deterioration in the Turkish vocation towards the Union.

The Black Sea Economic Cooperation forum (BSEC) is a very good example of the potential for more synergies. With its secretariat located in Istanbul and its Trade and Development Bank (BSTDB) based in Thessaloniki, the BSEC has an extensive 
institutional presence in areas of mutual concern. Founded on the belief that Black Sea states ought to deepen their relations and consolidate stability in the region, since its inception in 1992 BSEC has emphasized the principle of multilateral economic cooperation. EU enlargement has strengthened the Union's interest in Black Sea states, with Bulgaria and Romania now joining Greece as both EU and BSEC states. This facilitates cooperation by enabling access to EU financial resources, and combined with the trade mandate of BSEC offers promising collaborative prospects (Aybak 2001). BSEC has been an international organization since 1999, and its growth prospects are significant. Turkey and Greece could seek to entrench economic collaboration by use of BSEC's mandate.

\section{Interdependence and Greek-Turkey relations}

The contribution of non-state, economic actors in the process of Greek-Turkish cooperation should not be underestimated. The functions of the Greek-Turkish Chamber of Commerce and the Turkish-Greek Business Councils have acted as a spur for economic partnership and a channel of communication at difficult times. On the other hand, the dividing line between domestic and foreign policy remains quite clear in the Greek-Turkish paradigm, and though the role of the state as the sole actor for organizing this relationship has been dented, its powerful influence remains assured.

To what extent does the evolution of Greek-Turkish economic relations inform our theoretical understanding of interdependence between nations and actors within them? Using the yardstick first proposed by Kantian theorists, and borrowing from Pevehouse (2004), I purport to show that connection by using the evidence analysed in the previous sections and based on the following two categorizations.

Economic interdependence and the likelihood of military confrontation. Signs here are encouraging. Establishing direct correlations, let alone causations, is an arduous task, but we have empirical clues as to the possible connection between growing interdependence and the possibility of a military standoff. The 1996 Imia/Kardak crisis could have been repeated in the spring of 2005. The then Greek foreign minister Molyviatis was on a state visit to Ankara and while announcing the latest round of CBMs, a standoff occurred on the islet involving the Greek and Turkish coastguards and air force pilots. The situation was defused when Molyviatis embarked at once on negotiations with his Turkish counterpart, leading to a simultaneous withdrawal of the Turkish and Greek patrol boats (Çağlayan 2005; Kathimerini 2005). The 2005 incident demonstrates the progress that has yet to be made to completely normalize relations. Despite the continuing accusations and counter-accusations of border violations, however, the way the crisis was resolved and the swift return to normalcy suggest that the costs of brinkmanship are increasing. Disregarding the consequences that military confrontation over Imia/Kardak would have for bilateral economic cooperation (as well as for Turkey's EU vocation) is unlikely. The cancellation of a seismic survey on disputed continental shelf adds further credibility to the same argument. Piri Reis did not embark on the survey in the summer of 2001 after intensive consultations by the two Foreign Ministries; when in 1987 a similar voyage was conducted, the two countries almost engaged in armed confrontation (Tsakonas and Dokos 2004).

Economic interdependence leading to more political cooperation. Sequencing is important here. Notwithstanding the role played by the two business communities, it 
was the political leadership displayed by the two countries that signalled to the business world new economic opportunities. As the president of the Greek Enterprises Federation (SEV) put it during the 2008 Greek-Turkish Business Forum, 'the market can clear the path. But it is politics which places the concrete to make it a road' (To Vima, 3 February 2008; author's translation).

The Franco-German paradigm is not only the most successful example of cooperation in Europe, but also a source of inspiration for many in Greece and Turkey. It is true that this paradigm remains elusive, but it has nevertheless become a tangible goal. What is necessary is the elaboration of a long-term cooperation project outlining the exact conditions of economic complementarities and fostering a partnership premised on the aim of consolidating the undoubted gains of the rapprochement. Steps such as the establishment of a Business Council Greece-Turkey in 2007 (Lavidas 2008) will strengthen bilateral economic connections and provide a forum for the design of a long-term strategy. In the next phase of Greek-Turkish relations, institutionalized economic cooperation inside and outside the European Union is a sine qua non for progress in bilateral relations, all the time bearing in mind that the current stalemate in bilateral political relations may be a tolerable but, in the long run, hardly sustainable arrangement.

\section{Conclusion}

Greek-Turkish relations have long been characterized by antagonism and a zero-sum game approach. Starting from the late 1990s, and in a context of wider geopolitical and economic change, a rapprochement was reached after the initiatives of the Turkish and Greek foreign ministers. A decade later, the improvement in bilateral relations is tangible, and despite alterations in government, the determination to normalize relations persists. Economic cooperation through enhanced trade, joint ventures and FDI investments has played a crucial role in enlarging the prism through which the two sides view one another. The most important aspect of civil society diplomacy, business cooperation has made a critical contribution to the slow but real move away from an exclusively state-centred understanding of bilateral relations. Deals such as the NBG-Finansbank of 2006 open up further opportunities, and the existing institutional cooperation between the two business communities is a promising sign.

The transformative potential of the EU is well known to Greece and provides significant incentives for the political change of Greek behaviour towards Turkey's EU ambitions, as well as Turkey's own political transformation (Kirisçi 2002). On issues of FDI in particular, empirical evidence suggests a positive correlation between Greek investment decisions and progress towards EU accession by Balkan states (Kitonakis and Kontis 2008). The same logic could be applicable to GreekTurkish economic relations. However, the picture becomes complicated if one bears in mind that Turkey's EU membership remains an open-ended affair, and the set of obstacles towards its full membership persist. Should a scenario of anything less than full membership materialize, it is imperative that existent channels of collaboration be used so as not to turn a possible EU-Turkey rift into its bilateral Greek-Turkish variant. This is all the more important, considering the high degree to which Turkey's EU vocation affects bilateral economic relations. Also, the asymmetry recorded above, whereby Greece effectively exports capital to Turkey in return for goods, is unlikely to be overcome any time soon, even if the present financial and economic 
crisis were resolved. As Papadopoulos has argued (2008, 31), 'a factor that will tend, ceteris paribus, to restrain Turkish FDI into Greece in the medium term is Turkish entrepreneurs' preference for low-wage foreign sites'. Competitive advantage calculations stemming from a low-cost strategy are likely to keep FDI outflows from Turkey to Greece at their present low levels, over and above the real bureaucratic and administrative hurdles to which such ventures may be subject. In other words, GreekTurkish economic relations have some way to go before current asymmetries can be successfully addressed.

Interdependence theory captures the dynamics of Greek-Turkish partnership up to a certain point. The possibility of military confrontation has been reduced in the modern era. Non-state actors have been substantially emancipated from state authorities and are now able to set their own set of issues to state actors, expecting their response and encouragement. At the same time, it remains an open question whether or not economic relations have passed a certain point of dependence to politics, and whether a critical mass has by now been acquired that lends political relations vulnerable to economic interests. As Keohane and Nye state, 'it is better to raise the issue of governmental control as a question for investigation rather than to prejudge the issue at this point in terms of "loss of control"" (Keohane and Nye 1971, 343). In the GreekTurkish case study, such loss of control has hardly materialized. Regardless of the activism demonstrated by Greek and Turkish businesspersons, it was politicians that set the ground for the rapprochement in the 1990s, and it is still politicians who are tasked with the burden of resolving bilateral disputes.

This paper has sought to demonstrate that Greek-Turkish economic relations can be properly understood only in the context of wider economic transformations and political change affecting domestic institutions and structures. In that sense, economic relations are subject to global economic fluctuations. The recent negative turn in the global business cycle is bound to affect economic prospects in both states, with Greece's rather low trade pattern with Turkey providing an additional obstacle. Signs of a slowdown in economic activity abound, and governments throughout the world are currently working on damage limitation exercises. Greek-Turkish economic cooperation is likely to lose impetus over the next few years. Getting out of current difficulties with as little damage as possible seems a shared ambition for both countries' business communities and political elites.

\section{Acknowledgements}

Part of the research for this paper was conducted whilst the author was J.F. Costopoulos Junior Research Fellow in Greek-Turkish Relations at Istanbul Bilgi University. I wish to acknowledge the financial support of the J.F. Costopoulos Foundation and thank Harry Tzimitras, Umut Özkirimli and Yavuz Tüyloğlu for facilitating my stay at Bilgi. I also wish to thank all of my interviewees for their time. Ioannis N. Grigoriadis and an anonymous referee have provided valuable feedback and suggestions for improving earlier drafts of this paper. The usual disclaimer applies.

\section{Notes}

1. The term 'Golden Age' is here used rather loosely. 1950 to 1975 was a golden age for Western Europe in terms of growth and welfare, but in countries such as Greece, where the civil war traumas had yet to heal and the welfare state was hardly existent, the same term can only connote rapid rates of economic growth. 
2. Interview with Mr. Selim Egeli, Chairman of Turkish-Greek Business Council in Foreign Economic Relations Board (Diş Ekonomik İlişkiler Kurulu, DEIKK), March 2008.

3. Interview with Eurobank official, April 2008.

4. Figures are inexact, as the Greek and Turkish authorities report slightly different figures (see Papadopoulos 2008).

5. Interview with Mr. Selim Egeli, March 2008; interview with Eurobank official, April 2008.

6. Interview with Mr. Bülent Taş, Revenue Administration, June 2008. Mr. Taş was at the time head of the department responsible for the Double Taxation Agreement in the Turkish Ministry of Finance, and was personally involved in the negotiations.

7. Interview with Greek Consulate official to Turkey, February 2008.

8. Interview at Trade and Economic Affairs of the Greek Embassy to Turkey, February 2008.

9. FDI here means a) the establishment of a long-term relationship between the investor and the entity abroad and b) the ability by the investor to seriously affect the management of the entity (Kitonakis and Kontis 2008, 279).

10. Information obtained from the Trade and Economic Affairs Office of the Greek Embassy to Turkey, February 2008.

11. Interview with NBG official, March 2008.

12. Interview at Trade and Economic Affairs of the Greek Embassy, February 2008.

\section{Notes on contributor}

Dimitris Tsarouhas is Assistant Professor at the Department of International Relations, Bilkent University, Turkey.

\section{References}

Ak, R. 2007. Yunan Alpha, Abank için BDDK'dan izin alamadi! [Greek Alphabank not permitted [to buy] Alternatifbank from the Regulation Authority!]. Sabah, August 8.

Athanassopoulou, E. 1997. Blessing in disguise? The Imia crisis and Turkish-Greek relations. Mediterranean Politics 2, no. 3: 76-101.

Aybak, T. 2001. Black Sea Economic Cooperation (BSEC) and Turkey. In Politics of the Black Sea: Dynamics of cooperation and conflict, ed. T. Aybak, 31-60. London and New York: IB Tauris.

Bastian, J. 2004. 'Knowing your way in the Balkans': Greek foreign direct investment in Southeast Europe. Southeast European and Black Sea Studies 4, no. 3: 458-90.

Belge, T. 2004. Observations on civil society. In Voices for the future: Civil dialogue between Turks and Greeks, 27-32. Istanbul: Bilgi University Press.

Birand, M.A. 1991. Turkey and the Davos process: Experiences and prospects. In The Greek-Turkish conflict in the 1990s: Domestic and external influences, ed. D. Constas, 27-39. New York: St. Martin's Press.

Çağlayan, S. 2005. Despite confidence-building measures, dispute between Turkey and Greece continues. Journal of Turkish Weekly, April 14.

Couloumbis, T. 2003. Greek foreign policy: Debates and priorities. In Greece in the twentieth century, ed. T. Coulumbis, T. Kariotis and I. Bellou, 31-41. London: Frank Cass.

Cowles, M.G. 2003. Non-state actors and false dichotomies: reviewing IR/IPE approaches to European integration. Journal of European Public Policy 10, no. 1: 102-20.

Deutsch, K. 1957. Political community and the North Atlantic Area: International organization in the light of historical experience. Princeton, NJ: Princeton University Press.

Economides, S. 2005. The europeanisation of Greek foriegn policy. West European Politics 28, no. 2: 471-91.

Eurobarometer. 2006. Attitudes towards European Union enlargement. Special Eurobarometer 255. Brussels: European Commission.

- 2007. Public opinion in the European Union. Standard Eurobarometer 67. Brussels: European Commission.

Evin, A. 2005a. Changing Greek perspectives on Turkey: An assessment of the postearthquake rapprochement. In Greek-Turkish relations in an era of détente, ed. A. Çarkoğlu and B. Rubin, 4-20. London and New York: Routledge.

. 2005b. The future of Greek-Turkish relations. Southeast European and Black Sea Studies 5, no. 3: 395-406. 
Ferentinou, A. 2007. Yunanistan'da Finansbank üzerinden siyasi kavga [Political battle in Greece over Finansbank). Referans, February 10.

Grigoriadis, I.N., and A. Kamaras. 2008. Foreign direct investment in Turkey: Historical constraints and the AKP success story. Middle Eastern Studies 44, no. 1: 53-68.

Held, D. 1999. Global transformations. Oxford: Polity.

Heraclides, A. 2002. Greek-Turkish relations from discord to détente: A preliminary evaluation. The Review of International Affairs 1, no. 3: 17-32.

Honjo, K., and D. Chua. 2008. Greece: Selected issues IMF Country Report No. 08/147. Washington, DC: IMF.

Hope, K. 2008. Foreign relations: Blue-chip deals strengthen Turkish business ties. Financial Times, June 1.

Istanbul Chamber of Industry (Istanbul Sanayi Odasi). 2008. Yunanistan Ülke Raporu (Country Report: Greece), June. Istanbul: Istanbul Chamber of Industry.

Josselin, D., and W. Wallace, eds. 2001. Non-state actors in world politics. New York: Palgrave.

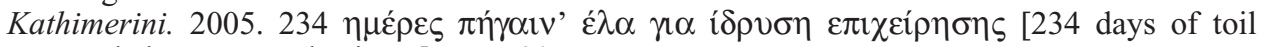
needed to set up a business]. May 30 .

Kathimerini. 2005. Imia incident ends by mutual agreement. (English edition). April 14.

Keohane, R.O., and J. Nye. 1971. Transnational relations and world politics: An introduction. International Organization 25, no. 3: 329-49.

- 1977. Power and interdependence: World politics in transition. Boston: Little Brown.

. 1998. Power and interdependence in the information age. Foreign Affairs 77, no. 5: 81-94.

Ker-Lindsay, J. 2007. Crisis and conciliation: A year of rapprochement between Greece and Turkey. London and New York: IB Tauris.

Keridis, D. 1999. Political culture and foreign policy: Greek-Turkish relations in the era of European integration and globalization. NATO Fellowship Report. Cambridge, MA: NATO.

Kirisçi, K. 2002. The 'enduring rivalry' between Greece and Turkey: Can 'democratic peace' break it? Alternatives 1, no. 1: 38-50.

Kitonakis, N., and A. Kontis. 2008. The determinants of Greek foreign direct investments in southeast European countries. Southeast European and Black Sea Studies 8, no. 3: 269-81.

Lavidas, A. 2008. Welcome address. UBCEE Quarterly Bulletin 4, 1-2.

Millas, I. 2006. Tourkokratia: History and the image of Turks in Greek literature. South European Society \& Politics 11, no. 1: 47-60.

Öniş, Z. 2003. Domestic politics versus global dynamics: Towards a political economy of the 2000 and 2001 financial crises in Turkey. In The Turkish economy in crisis, ed. Z. Öniş and B. Rubin, 1-30. London: Frank Cass.

Özel, S. 2004. Turkish-Greek dialogue of the business communities. In Voices for the future: Civil dialogue between Turks and Greeks, ed. T. Belge, 163-8. Istanbul: Bilgi University Press.

Özkırımlı, U., and S.A. Sofos. 2008. Tormented by history: Nationalism in Greece and Turkey. London: Hurst and Company.

Pagoulatos, G. 2003. Greece's new political economy: State, finance and growth from postwar to EMU. Basingstoke: Palgrave Macmillan.

Papadopoulos, C.A. 2008. Greek-Turkish economic cooperation: Guarantor of detente or hostage to politics? South East European Studies at Oxford (SEESOX) Occasional Paper No. 8/08, March.

Pevehouse, J.C. 2004. Interdependence theory and the measurement of international conflict. The Journal of Politics 66, no. 1: 247-66.

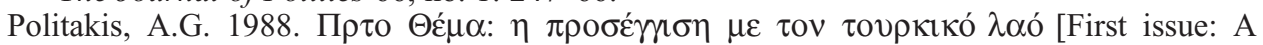
rapprochment with the Turkish people]. Athens: Papazisis.

Rumelili, B. 2005. Civil society and the Europeanization of Greek-Turkish cooperation. South European Society and Politics 10, no. 1: 43-54.

Saner, R., and L. Yiu. 2003. International economic diplomacy: Mutations in post-modern times. Discussion Papers in Diplomacy, Netherlands Institute of International Relations.

Scholte, J.A. 2000. Globalization: a critical introduction. London: Macmillan. 
Sotiropoulos, D. 1993. Colossus with feet of clay: The state in post-authoritarian Greece. In Greece, the New Europe and the changing international order, ed. H.J. Psomiades and S.B. Thomadakis, 43-56. New York: Pella Publishing.

Şenses, F. 2003. Economic crisis as an instigator of distributional conflict: The Turkish case in 2001. In The Turkish economy in crisis, ed. Z. Öniş and B. Rubin, 92-119. London: Frank Cass.

Tocci, N. 2005. Europeanization in Turkey: Trigger or anchor to reform? South European Society and Politics 10, no. 1: 73-83.

Togan, S., and H. Ersel. 2003. Macroeconomic policies for Turkey's accession to the EU. In Turkey: Economic reform and accession to the European Union, ed. B. Hoekeman and S. Togan, 3-36. Washington: World Bank.

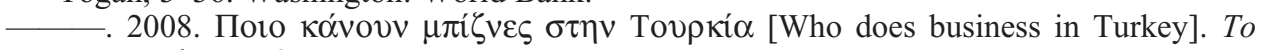
Vima, February 3.

Toprak, B. 1993. Civil society in Turkey. In Civil society in the Middle East, Vol. 2, ed. A.R. Norton, 87-118. Boston: Brill.

Tsakalotos, E. 1991. Alternative economic strategies: The case of Greece. Aldershot: Avebury.

Tsakonas, P. 2001. Turkey's post-Helsinki turbulence: Implications for Greece and the Cyprus issue. Turkish Studies 2, no. 2: 1-40.

Tsakonas, P.J., and T.P. Dokos. 2004. Greek-Turkish relations in the early twenty-first century: A view from Athens. In The future of Turkish foreign policy, ed. L.G. Matin and D. Keridis, 101-26. Cambridge and London: MIT Press.

Ugur, M. 2000. Europeanization and convergence via incomplete contracts? The case of Turkey. South European Society and Politics 5, no. 2: 217-42.

UNCTAD. 2007. World investment report: Transnational corporations, extractive industries and development. New York and Geneva: United Nations.

Undersecretariat of Treasury (Turkey), 2008. Foreign direct investments in Turkey 2007. Ankara: General Directorate for Foreign Investment.

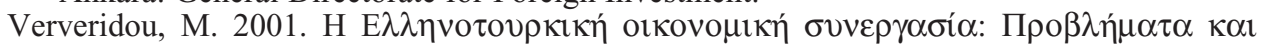

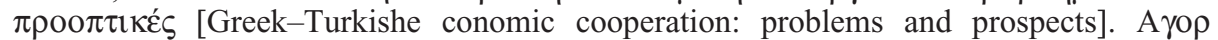
$\chi \omega \rho i ́ s$ Vvopo [Market Without Frontiers] 7, no. 1: 95-112.

Volkan, V.D., and N. Itzkowitz. 1994. Turks and Greeks: Neighbours in conflict. Huntingdon: The Eothen Press.

Waltz, K. 1979. Theory of international politics. New York: McGraw Hill. 